\title{
A Study on the Business Innovation and the Management Mode of Business Cooperation between Banks and Trust
}

\author{
Xiaoyu Li \\ Business Administration School, North China Electric Power University, Beijing 102206, China
}

\begin{abstract}
Banking is an industry with high intensity and fast update of knowledge, information, and technology. Innovation is a key element for commercial banks' survival and development. In the self-development process, China commercial banks cooperate with trust companies in business and create new financial products, strengthening management and risks control. By this way, banks can find out new profit rising point and the state-owned commercial banks can improve their comprehensive competitive strength. This paper analyzes the present situation and problems of China's banking-and-trust operations, advancing effective business innovation and management mode.
\end{abstract}

Keywords: State-owned commercial bank, Business cooperation between banks and trust, Innovation, Management mode

\section{Introduction}

Along with the gradual perfect of policy and legal platform and the continuous enhancement of social public rational investment idea, China's trust meets its opportunity of development. Trust company, as the only institution that can make fully use of financial market and connect industries and financial market, can provide with all kinds of financial services, from corporate merge and purchase and reengineering to system transformation to financial and renting. As trust company pushes innovation in financial market, it brings about bright prospect for the cooperation between banking and trust. By cooperating with trust companies, China's state-owned commercial banks can achieve multiple income structure and diverse business types, improving the proportion of middle business income, and decreasing costs of operation. State-owned commercial banks should make best use of advantages in capitals, settlement, net, and customers, pay more attentions on and grasp opportunities in financial innovation and business exploration, cooperate with trust companies to make innovation actively, enhance business management and risks control over banks' trust operation, and improve the comprehensive competitive strengths.

\section{The present situation and problems in state-owned commercial banks' business cooperation with trust}

The cooperation between banking and trust has become a new hot in financial cooperation filed. Some state-owned commercial banks have business partnership with domestic trust companies. They cooperate in many aspects by signing business cooperation agreements. In a sense, the cooperation drives relevant business operation's development in state-owned banks. However, there are many problems in the business cooperation between state-owned commercial banks and trust companies at present.

\subsection{The cooperation between banks and trust is in a low level and lack of business innovation.}

In the cooperation between banks and trust, as domestic trust companies make self business innovation, they constantly ask banks in cooperation to make innovations. However, because some branches of state-owned banks fail to analyze customers' needs thoroughly, they are not sensitive to market changes. Products and services cannot achieve timely innovation. All these facts affect the cooperation between banks and trust companies. In specific, less trust companies keep close cooperation with banks. And the cooperation fields become narrower. The business products are unilateral and lack of innovation capability. Market competence is weakened. These results decrease customers' satisfaction to a great degree, affect the maintenance of customer relationship, and restrain the further development of banking-and-trust cooperation in state-owned commercial banks.

\subsection{The approval of business operation is complicated, what affect the marketing efficiency and effect.}

Shortage of innovation in banking-and-trust cooperation will cause the high homogeneity of banks' services at the same time. Banks compete for more market shares. The competition becomes fiercer. Comparing with commercial banks with shareholding systems, state-owned commercial banks' branches have to gain approval in order to cooperate with trust companies, which is complicated and time-consuming. Meanwhile, in contrast with state-owned banks, some trust companies are small, and some at the developing stage in new operation process and market. Therefore, the cooperation is relatively small, which can not win sufficient attentions from the management department of state-owned commercial 
banks. As a result, the approval will consume more time. However, market opportunity does not wait there, plus the branches of state-owned banks can not reply for their customers clearly and timely, what will affect the competence of cooperation business between state-owned commercial banks and trust companies. As a result, trust companies may lose their customers.

\subsection{Lack of specialized marketing team and sufficient talents.}

Banking-and-trust cooperation covers a large scope and needs strong specialization. Therefore, workers of state-owned commercial banks who are engaged in banking-and-trust cooperation should not only possess skilled marketing techniques but also grasp sufficient specialized knowledge concerning banking assets, debts, middle business field, trust industry, trust products, laws and regulations. Because of insufficient training for relevant business operations, knowledge, and techniques, state-owned commercial banks can not find out enough qualified marketing workers for the banking-and-trust cooperation at present. In a short period, specialized talents are in short.

\section{The product innovation for state-owned commercial banks' cooperation with trust}

The key of product innovation for state-owned commercial banks' cooperation with trust lie in banks' complete understanding toward trust and whether banks achieve an optimal organic combination with trust needs. State-owned commercial banks should make full use of self advantages. As state-owned commercial banks advance product integration schemes for trust companies, they should make researches on the products cooperation and innovation and apply them to the cooperation, exploring new financial products that meet the market needs.

\subsection{Trust plan can help state-owned commercial banks to deal with their bad assets properly.}

The high bad assets have troubled state-owned commercial banks for a long time. Trust and market principles provide possibilities of dealing with mortgage assets properly. China's state-owned commercial banks can make best use of trust companies advantages in flexible operation forms, diverse business ways, and rich products and tools to attract market capitals to participate in dealing with bad assets by means of trust. With the banking-and-trust cooperation mode, banks can turn their preferential right to benefit to investors, which can help banks to gain returns from partial assets, improving the effect of asset disposition. Meanwhile, because banks still have the subordinated right to benefit. Therefore, they can enjoy complete right even though they have already realized their preferential right to benefit

3.2 Make best use of advantages in scale and net and enlarge the middle business cooperation field between banks and trust.

In contrast with small- and medium-sized commercial banks, state-owned commercial banks possess evident advantages in settlement net, operation network, and electronic level. By enhancing middle business operation cooperation with trust companies, state-owned commercial banks can effectively enlarge income resources from middle business operation. The cooperation concerns three aspects, namely settlement, agent, and card. In the aspect of settlement, banks can provide with agent services for trust companies in self-owned capitals' settlement and transfer. Besides, banks can use cash management products to help trust companies achieve the effective setting of accounts and the unified management of capitals. In the aspect of agent, banks can provide with agent service for trust plan's capital payment operations and trust loans' interest payment operations. At the same time, banks can rely on trust companies' wide customer resources to develop credit card business.

\subsection{Develop cooperation in credit assets' transfer business and improve the liquidity of banks'credit assets.}

Many problems exist in the credit assets transfer between banks. The most important one is the bargainer's loss of customers. The participation of trust companies in the credit assets' transfer market can rightly satisfy banks' strong desire for sustaining customer sources. In specific, it includes "buy-out operation" and "repurchase operation". In the buy-out operation, banks transfer the credit right to trust companies. As loans are terminated, borrowers will return principals and interests to trust companies. In the repurchase operation, banks take credit assets as mortgage to realize a short-term transaction of capital. By cooperating with trust companies in credit asset transfer, banks can improve their asset structure, adjust the assets-liabilities ratio, avoid capitals' liquidity risks, and create new profit rising point. For trust companies, loans transferred by banks are mostly better assets that can generate expected profits.

\subsection{Enhance trust cooperation in accounts receivable and decrease loan risks.}

The trust of accounts receivable is a kind of new-developed banking-and-trust cooperation product that benefit the bank, the trust company, and the enterprise at the same time. In detail, the enterprise is the trust settler, the trust company the trustee, and the bank the trust beneficiary. The three sides sign trust contract. The enterprise grants accounts receivable to the trust company. The trust company is responsible for supervising the enterprise to take accounts receivable back. The return to accounts receivable belongs to the bank. At the same time, the bank signs a loan contract with the enterprise and provides with loans for the enterprise. For the bank, this banking-and-trust cooperation mode can improve the loan safety. The independent character of trust assets separates accounts receivable from cooperate assets. No matter what problems the enterprise will have, the bank still possess the return to the accounts receivable, which 
guarantees the safety of bank's loans.

\subsection{Enhance the share of customer sources and project sources and realize the advantage complement}

Because of local elements and government background, trust companies can easily obtain better projects and have powerful customers. State-owned commercial banks can emphasize on sharing customer resources and project resources with trust companies, by which they can realize the advantage complement and the mutual development.

\section{The development strategy and management mode for state-owned commercial banks developing banking- and-trust business}

The general development strategy for state-owned commercial banks include: take detailed researches on characters of trust, insist on principle of emphasizing both business exploration and risks defense, exert the general advantages of state-owned banks completely, grasp market opportunities fully, develop long-term and strategic cooperation with trust companies that have strong comprehensive powers, high management levels, and great market influences, take the share of customer resources as the way, and product innovation the motive, work hard to explore banking-and-trust business market. In persisting in the general strategy, state- owned commercial banks should combine it with relevant flexible mechanism together to ensure that the innovation mechanism can stay in a best state under numerous uncertainties.

4.1 Emphasize on the communication and relation with industrial supervision department and make researches on relevant policies and laws.

At present, the law of trust is on the way of gradual perfection. State-owned commercial banks must especially pay more attentions on communicating with industrial supervision department and make researches on policies in advance. And the researches should have a sense of prediction, flexibility, and sensitivity. Besides, the state-owned commercial banks should regulate their product operation mode continuously and adjust their product design ideas and marketing strategy. Meanwhile, they must transfer the trends of trust, the statistical data, and the self-restrained supervision measures to the branches in time.

4.2 The top management level should provide with timely and proper directions for the banking-and-trust cooperation in order to perfect the three-level associated marketing system.

Base on researches and analyses on trust policies and market changes, the top management level of the state-owned commercial bank should study the grave problems emerged in the cooperation with trust companies carefully and make up a proper marketing scheme for the whole bank, guiding the exploration of banking-and-trust cooperation. For the core customers, the bank can adopt the three-level (namely the head offices, the local banks, and the branches) associated marketing, applying a dynamic management. Set up customer manager teams and implement the chief customer manager system. Perfect the business coordination mechanism. Construct a rule of business coordination conference in which the marketing sector serves as the leader and other relevant sectors participate. For customers' needs, they should give timely response and solve them properly. Exert state-owned commercial banks' comprehensive advantages and effectively improve market competence and business response capability.

\subsection{Segment the market and implement the differentiated marketing strategy.}

Commercial banks should insist on the principle of taking customers as the core. Segment the customer market further. Design personalized marketing strategy and implement differentiated marketing strategy. According to trust companies' capital strengths, operations, management, business innovation, market exploration, corporate image, and other indicators, the banks can classify the trust companies into strategic cooperation type, the core cooperation type, the common cooperation type, and the prudent cooperation type. Implement a core marketing for the trust company that has strong capital strengths, nice operations, effective management, powerful production innovation, better corporate image, and excellent market exploration ability, and meet its needs overall. At the same time, pay more attentions on banking-and-trust product innovation and development. Integrate trust companies' research and development resources with commercial banks' comprehensive advantages together. Master the market changes. Produce new products constantly. Develop the banking-and-trust cooperation to a deeper and larger degree.

4.4 Constitute a perfect regulation system, emphasize on empowerment management, and make efforts to defend risks.

Because trust companies have relatively powerful innovation capability, they demand for more banking-and- trust cooperation products, what increases difficulties for empowerment. Therefore, state-owned commercial banks should set up relevant credit assessment system to defend risks. In special, a pre-warning system is necessary to response to diverse needs that may bring about risks because of informal and abnormal behaviors.

\subsection{Perfect the internal evaluation and encouragement mechanism, and implement the banking-and-trust business'} customer manager system.

State-owned commercial banks should popularize the banking-and-trust business' customer manager system in the whole country. For the qualified trust company, they should arrange the chief customer manager and construct a 
"communication system" with it, enhancing mutual understanding and communication. Meanwhile, state-owned commercial banks should perfect the internal evaluation and encouragement system constantly and construct a set of indicator system to assess the banking-and-trust business. The head office can make scientific and reasonable evaluation on customer managers' performance based on a series of qualitative and quantitative indicators, and motivate customer managers' enthusiasm in work by encouragement mechanism.

4.6 Stress on professional training and improve banking-and-trust business customer managers 'integrated quality.

Highly qualified customer managers are the foundation of commercial banks' banking-and-trust business. In order to realize the close meeting of banking-and-trust products and market needs, banks must possess a batch of marketing talents and elites who have advanced marketing methods and rich business knowledge. Correspondingly, a systematic training system is necessary. In order to achieve a rational talents combination and optimal arrangement, banks should insist on the principle of customer first. By a professional training program, all employees can possess industrial sensitivity and relatively higher marketing capability. As a result, the state-owned commercial bank will possess a marketing team that can help the bank to cultivate a close relation with trust companies and gain market competence.

4.7 Construct a decision-support and information management system for banking-and-trust business' new products and drive the experience communication among banks.

For commercial banks, the new products' decision procedure must be simple and effective. Because the new product extremely depends on right time and right opportunity and can be easily copied, the banks' decision system must emphasize on time. Therefore, the decision system has to rely on other special support systems. At the same time, make best use of present business platform and construct a banking-and-trust business information management system, by which the bank can achieve a comprehensive management on trust companies' information, realizing electric information retrieving, statistics, and empowerment. All customer managers in the bank can communicate easily and report for their performance. The electric technology helps to improve work efficiency and realize the share of information resources.

\section{Conclusion}

Because there are still many problems in the banking-and-trust business, it is urgent to enhance the business cooperation between state-owned commercial banks and trust companies, and the product innovation. China's state-owned commercial banks should make full use of self advantages, grasp opportunities of financial innovation and business exploration, implement the product cooperation and innovation with trust companies, achieve multiple income structure and diverse business types, improve middle business income, decrease operation costs, enhance banking-and-trust business management and risks defense, and improve their comprehensive competence.

\section{References}

Da, Xiaoqi. (2003). Probe into the trust cooperation in banks. Friends of Accounting. No.6.

Lan, Yuling. (2007). Analyze on the trust service in private banking service. Seeker. No.2.

Li, Xiaofang. \& Tong, Changfeng. (2007). Cooperating with trust and house rent: the banking industry has a bright prospect. Western Forum. No.4. 